\title{
Injeksi Intravitreal Triamsinolon Pada Central Retinal Vein Occlusion (CRVO)
}

\author{
Sherly Muchlis ${ }^{1}$, Weni Helvinda ${ }^{2}$
}

\begin{abstract}
Abstrak
Central Retinal Vein Occlusion (CRVO) adalah suatu gangguan kondisi pembuluh darah retina yang dapat menyebabkan morbiditas okular yang signifikan dengan gambaran klinis oklusi atau trombosis dari vena sentralis retina mengakibatkan statis vena, edem papil, perdarahan pre retina dan perdarahan difus di lapisan serat saraf serta cotton wool spots yang menghasilkan gambaran fundus the blood and thunder. Penatalaksanaan CRVO adalah mengatasi underlying disease dan gejala sisa dari CRVO yaitu edem makula dan neovaskularisasi (NV). Penatalaksanaan edem makula pada CRVO dapat berupa observasi, terapi kortikosteroid, dan intravitreal anti VEGF. Untuk mengatasi NV okular seperti laser fotokoagulasi, dan terapi medikamentosa. Selain itu terdapat beberapa terapi alternatif CRVO yaitu chorioretinal venous anastomosis, tissue plasminogen activator, vitrektomi dan radial optic neurotomy. Dilaporkan seorang wanita usia 59 tahun dengan CRVO OS (tipe iskemik), moderat NPDR OD dan katarak imatur ODS direncanakan injeksi intravitreal triamsinolon OS $4 \mathrm{mg} /$ 0,1 cc di kamar operasi dalam keadaan steril. Tajam penglihatan mata kiri meningkat menjadi 1/60 pada minggu ke-4 dan minggu ke-8 kontrol dan perbaikan pada fundoskopi mata kiri. CRVO biasanya terjadi unilateral, disertai dengan penurunan penglihatan tanpa rasa sakit. Terapi injeksi intravitreal triamsinolon (IVTA) diberikan untuk mengobati edema makula pada CRVO.
\end{abstract}

Kata Kunci: central retinal vein ocussion, oklusi vena, IVTA, trombogenesis

\begin{abstract}
Central retinal vein occlusion (CRVO) is a disorder of the condition of the retinal blood vessels that can cause significant ocular morbidity with a clinical picture of occlusion or thrombosis of the central retinal vein resulting in venous static, papillary edema, pre retinal bleeding and diffuse bleeding in nerve fiber layers and cotton wool spots that produce an image of the blood and thunder fundus. CRVO management is to overcome the underlying disease and sequelae of CRVO, namely macular edema and neovascularization (NV). Management of macular edema in CRVO can be in the form of observation, corticosteroid therapy, and intravitreal anti VEGF. To deal with ocular NV such as photocoagulation laser and medical therapy. In addition, there are several alternative therapies for CRVO, namely chorioretinal venous anastomosis, tissue plasminogen activator, vitrectomy, and radial optic neurotomy. It has been reported a 59-year-old woman with CRVO OS (ischemic type), moderate NPDR OD and immature cataract ODS planned intravitreal injection of triamcinolone OS $4 \mathrm{mg} / 0.1 \mathrm{cc}$ in the operating room in a sterile state. Visual acuity of the left eye increased to $1 / 60$ at the fourth and eighth week of control and improvement fundoscopy of the left eye. CRVO usually occurs unilaterally, accompanied by decreased vision without pain. Intravitreal triamcinolone (IVTA) injection therapy is given to treat macular edema in CRVO.
\end{abstract}

Keywords: central retinal vein occlusion, venous occlusion, IVTA, thrombogenesis

Affiliasi penulis: ${ }^{1}$ Dinas Kesehatan PEMKO Pekanbaru. ${ }^{2}$ Bagian IImu Kesehatan Mata, Fakultas Kedokteran, Universitas Andalas, Padang Korespondensi:sherlymuchlis@gmail.com,

helvindawenispm@gmail.com. Telp: 08129512433

\section{PENDAHULUAN}

Central retinal vein occlusion (CRVO) adalah suatu gangguan kondisi pembuluh darah retina yang dapat menyebabkan morbiditas okular yang signifikan. Oklusi atau trombosis dari vena sentralis retina 
mengakibatkan statis vena, edem papil, perdarahan pre retina dan perdarahan difus di lapisan serat saraf serta cotton wool spots yang menghasilkan gambaran fundus the blood and thunder. Berdasarkan lokasi oklusi, kelainan tersebut diklasifikasikan menjadi dua tipe yang berbeda. Tipe pertama, sumbatan terjadi pada vena sentralis retina, dan yang kedua sumbatan terjadi pada vena cabang. Sumbatan paling sering terjadi pada persilangan dengan arteri retina. Sumbatan pada vena sentralis retina biasanya terletak pada daerah proksimal dari lamina kribosa atau tepat pada lamina yang merupakan tempat keluar vena sentralis. ${ }^{1,2}$

Prevalensi sumbatan vena retina berkisar antara $1 \%$ - $2 \%$ pada orang berusia diatas 40 tahun dan mengenai 16 juta orang di seluruh dunia. Sumbatan vena cabang terjadi empat kali lebih sering dibandingkan dengan sumbatan vena sentralis retina Pada sebuah studi kohort, ditemukan angka kejadian oklusi pada vena cabang retina sebesar 1,6\%. Oklusi vena retina bilateral jarang terjadi (kira-kira 5\%), namun pada $10 \%$ pasien dengan sumbatan pada vena cabang unilateral, dikelak kemudian hari dapat ditemukan oklusi pada mata sebelahnya. Sumbatan pada vena cabang maupun vena sentral dibagi menjadi sumbatan non iskemik (perfusi) dan iskemik (non perfusi). ${ }^{2}$ Setiap kategori berpengaruh terhadap prognosis dan hasil pengobatan. Angka kejadian pada laki-laki dan perempuan adalah sama dan terutama terjadi pada usia diatas 65 tahun. Pada kelompok usia tersebut, biasanya CRVO berhubungan dengan penyakit vaskular sistemik seperti diabetes mielitus dan hipertensi. Sedangkan pada pasien usia muda, CRVO biasanya terjadi pada pasien yang memiliki riwayat tingkat kekentalan darah yang tinggi atau proses inflamasi. ${ }^{3}$

Gambaran klinis pasien CRVO biasanya datang dengan keluhan penurunan visus mendadak yang tidak disertai nyeri, tetapi bisa juga dengan keluhan penurunan visus yang perlahan-lahan, hal ini $d i$ korelasikan dengan oklusi yang lebih ringan. CRVO biasanya unilateral, namun dalam waktu tahunan, resiko berkembangnya oklusi vaskular retina pada mata sebelahnya kira-kira $1 \%$ pertahun dan diperkirakan meningkat $7 \%$ dalam waktu lima tahun sejak onset CRVO pada mata yang pertama. ${ }^{1,2}$
Terapi CRVO ditujukan langsung untuk mengatasi akibat dari CRVO yaitu edem makula dan neovaskularisasi. Terdapat berbagai pilihan terapi untuk manajemen edem makula pada CRVO seperti observasi, kortikosteroid dan anti VEGF. Penatalaksanaan neovaskularisasi berupa laser foto koagulasi dan medikamentosa. Kini telah dilakukan berbagai studi tentang penggunaan kortikosteroid pada pasien oklusi vena retina. Tindakan ini diharapkan dapat menurunkan angka tindakan operasi sehingga risiko tindakan lebih minimal dengan menggunakan Intravitreal Triamcinolone Acetonide (IVTA). ${ }^{1,2}$

Penggunaan IVTA pada CRVO untuk mengatasi edem makula dan inflamasi intraokular dimana IVTA bisa meminimalisir efek sistemik dari kortikosteroid dan memaksimalkan efek lokal steroid melalui blood retinal barrier. Triamcinolone acetonide adalah suatu kortikosteroid golongan agonis sintetik glukokortikoid yang berperan dalam menghambat jalur inflamasi dimana menghambat pelepasan asam arakidonat dan turunannya. Pada penelitian SCORE didapatkan keberhasilan yang tinggi penggunaan IVTA dalam mengatasi edem makula pada CRVO dalam 12 bulan. Pada laporan kasus ini akan dibahas mengenai IVTA pada CRVO disertai follow up dan pembahasan efektifitas intravitreal triamcinolon acetonide pada pasien ini. ${ }^{3,4}$

\section{KASUS}

Ny L umur 59 tahun, datang ke poliklinik mata RSUP Dr M Djamil Padang pada tanggal 25 November 2015 dengan keluhan penglihatan mata kiri terasa kabur sejak \pm 2 bulan yang lalu. Penglihatan mata kiri terasa kabur sudah sejak \pm 1 tahun yang lalu, perlahan-lahan terasa semakin kabur sejak \pm 2 bulan ini. Riwayat penyakit DM diakui sudah sejak \pm 9 tahun yang lalu, pasien tidak rutin minum obat. Riwayat darah tinggi disangkal. Riwayat kolesterol tinggi disangkal. Riwayat pemakaian KB suntik diakui sudah sejak \pm 20 tahun yang lalu .

Pada pemeriksaan oftalmologi didapatkan visus mata kanan 5/10, pupil reflek tidak langsung (+) menurun, lensa mata kanan keruh subkapsul posterior. Funduskopi retina mata kanan didapatkan 
perdarahan (dot, blot). Status oftalmologi mata kiri didapatkan visus mata kiri 1/2 / 60, pupil RAPD (+), lensa keruh subkapsul posterior, funduskopi mata kanan didapatkan papil edem tertutup perdarahan, pembuluh darah tortositas vena meningkat, retina terdapat perdarahan (flame shaped) di 4 kuadran dan refleks fovea (-) tertutup perdarahan.

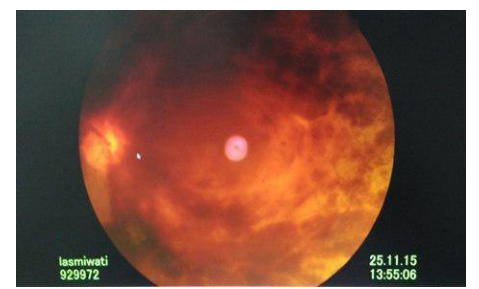

Gambar 1. Foto fundus OS, kesan CRVO OS

Pasien didiagnosis dengan CRVO OS (tipe iskemik), moderat NPDR OD dan katarak imatur ODS direncanakan injeksi intravitreal triamsinolon OS.

Pada follow up minggu ke 4 didapatkan peningkatan tajam peningkatan menjadi $1 / 60$ dan perbaikan pada funduskopi.

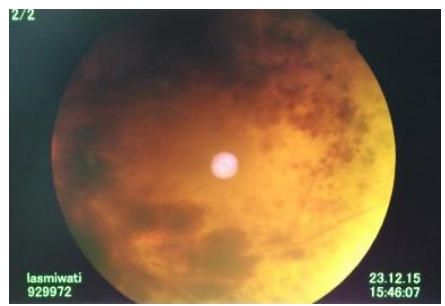

Gambar 2. Foto fundus OS, kesan CRVO OS dengan perbaikan

Pada follow up minggu ke 8 didapatkan visus tetap 1/60 dan funduskopi terdapat perbaikan, akan tetapi disertai perdarahan sub hyaloid.

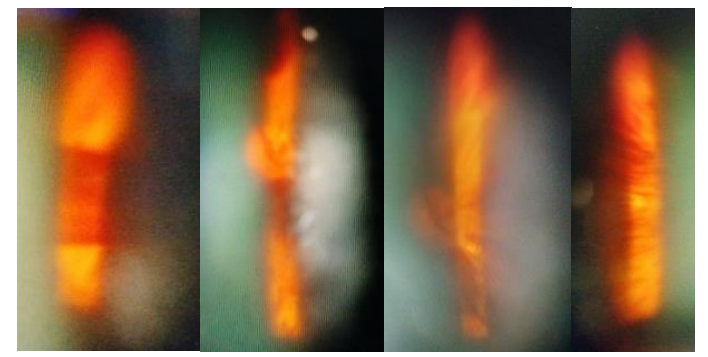

Gambar 3. Foto fundus OS, kesan CRVO OS denganperbaikan + perdarahan sub hyaloid
Tanggal 21 januari 2016

Hasil glukosa darah puasa $137 \mathrm{mg} / \mathrm{dl}$, glukosa darah 2 jam PP 393 mg/dl, total kolesterol 247 mg/dl, HDL 67 mg/dl, LDL kolesterol 160 mg/dl, trigliserida 98 $\mathrm{mg} / \mathrm{dl}, \mathrm{Hb} 12,6 \mathrm{gr} / \mathrm{dl}$, leukosit 5200/mm³, LED $5 \mathrm{~mm}$,

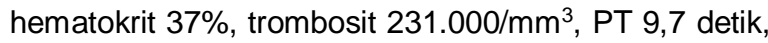
APTT 39,8 detik. Diagnosis bagian penyakit dalam: adalah DM tipe 2 + dyslipidemia. Terapi: Novorapid $3 \times 5 \mathrm{U}$, atorvastatin $1 \times 20 \mathrm{mg}$.

Pada kasus CRVO ini telah diberikan injeksi intravitreal triamsionolon dengan dosis $4 \mathrm{mg} / 01 \mathrm{ml}$. Dalam 1 vial awalnya dosis $40 \mathrm{mg}$, kemudian dilakukan pengenceran dan pengendapan hingga didapatkan konsentrasi akhir $4 \mathrm{mg}$ / 0,1 ml. Persiapan obat dilakukan di kamar operasi dalam keadaan steril.

\section{PEMBAHASAN}

Anamnesis didapatkan penglihatan mata kiri terasa kabur sejak \pm 2 bulan yang lalu. Mata kiri terasa kabur sudah sejak \pm 1 tahun yang lalu, perlahan-lahan terasa semakin kabur sejak \pm 2 bulan ini. Riwayat penyakit DM diketahui sejak \pm 9 tahun yang lalu, pasien tidak rutin kontrol. Riwayat pemakaian KB suntik sejak \pm 20 tahun yang lalu. Faktor resiko pada pasien ini adalah usia, dimana usia merupakan faktor resiko utama CRVO. Onset CRVO pasien usia diatas 50 tahun adalah 90\%. Faktor resiko lainnya adalah diabetes mielitus dan pemakaian kontrasepsi.

Menurut penelitian, diabetes melitus lebih sering menjadi faktor resiko CRVO tipe iskemik. Faktor resiko lain CRVO adalah hipertensi, hiperlipidemia, pemakaian kontrasepsi oral dan diuretik. Pasien ini menyangkal memiliki hipertensi dan hiperlipidemia. Pada pasien ini, ditemukan visus mata kiri 1/2/ 60 dan RAPD (+). Oklusi vena retina biasanya terjadi mendadak, unilateral, disertai penurunan visus tanpa rasa nyeri. Pasien ini penglihatan mata kiri kabur dirasakan sejak \pm 2 bulan yang lalu. Penglihatan mata kiri kabur sudah dirasakan sejak \pm 1 tahun yang lalu, namun dirasakan semakin kabur sejak 2 bulan ini. Penyebab penurunan visus yang paling sering pada pasien oklusi vena adalah edem makula dengan perfusi ataupun non perfusi. Tingkatan kehilangan tajam penglihatan bergantung pada luasnya keterlibatan retina dan status perfusi makula. 
Penyebab penurunan visus lainnya adalah neovaskularisasi (NV), perdarahan vitreus, ablasio retina, glaukoma neovaskuler (NVG). 5,6

Pada funduskopi ditemukan tortositas vena meningkat dengan perdarahan pada empat kuadran retina, edem retina dan yang sering ditemukan juga adalah cotton wool spot. Hal ini didapatkan pada funduskopi mata kiri pasien ini.

Oklusi vena retina memiliki prevalensi 1-2\% pada setiap orang yang berusia 50 tahun ke atas dan mempengaruhi lebih kurang 16 juta orang di seluruh dunia. Pada sebuah penelitian yang dilakukan di Amerika Serikat, prevalensi oklusi vena retina cabang mencapai $0,6 \%$ sementara prevalensi dari oklusi vena retina sentral hanya $0,1 \% .{ }^{6}$ Oklusi pada vena retina cabang 4 kali lebih sering terjadi daripada oklusi vena retina sentral. Sementara itu oklusi vena retina bilateral juga sering terjadi, walaupun pada $10 \%$ pasien dengan oklusi pada satu mata, oklusi dapat berkembang di mata lainnya seiring dengan berjalannya waktu. ${ }^{3}$ Adapun oklusi vena retina ini sering dihubungkan dengan penyakit-penyakit dalam bagian penyakit dalam. Hal yang paling umum diketahui adalah hubungan oklusi vena retina dengan gangguan vaskular sistemik seperti hipertensi, arteriosklerosis, dan diabetes mielitus dan glaukoma. Beberapa penelitian juga menemukan adanya peningkatan risiko terjadinya oklusi vena retina pada pasien dengan arteriopati maupun pasien dengan kadar glukosa darah dan tekanan darah arteri yang tinggi. ${ }^{6}$

Pada tanggal 21 januari 2016 didapatkan hasi laboratorium: Glukosa darah puasa 137 mg/dl, glukosa darah 2 jam post-prandial $393 \mathrm{mg} / \mathrm{dl}$, total kolesterol 247 mg/dl, HDL 67 mg/dl, LDL kolesterol 160 mg/dl. Pasien kemudian dikonsulkan ke bagian penyakit dalam dan didiagnosis DM tipe 2 dengan dislipidemia dan mendapatkan terapi Novorapid 3x5 U, atorvastatin 1x20 mg. Diabetes mielitus dan dislipidemia merupakan salah satu faktor resiko terjadinya CRVO.

Penyakit sistemik juga dapat menyebabkan oklusi vena retina, diantaranya adalah diabetes melitus, hipertensi, aterosklerosis, glaukoma, hypercholesterolemia, hyperhomocysteinemia, systemic lupus eritematosus (SLE), sarcoidosis, tuberculosis, syphilis, resistensi protein C (faktor $\mathrm{V}$ Leiden), defisiensi protein $\mathrm{C}$ dan $\mathrm{S}$, penyakit antibodi antiphospholipid, multiple myeloma, cryoglobulinemia, leukemia, lymphoma, Waldenstrom macroglobulinemia, polisitemia vera, dan sickle cell disease. Penyebab lokal dari oklusi vena retina adalah trauma, glaukoma, dan lesi struktur orbita. ${ }^{7}$

Oklusi vena retina adalah blokade dari vena yang membawa darah keluar dari retina. Oklusi vena retina diklasifikasikan berdasarkan lokasi di mana obstruksi terjadi. Obstruksi vena retina pada saraf optik diklasifikasikan sebagai oklusi vena retina sentral, dan obstruksi pada cabang vena retina diklasifikasikan sebagai oklusi vena retina cabang. Dua klasifikasi ini memiliki perbedaan dan kemiripan pada patogenesis dan manifestasi klinis. Oklusi vena retina secara umum dibagi lagi menjadi tipe iskemik dan non iskemik. CRVO terjadi akibat adanya trombus di dalam vena retina sentral pada bagian lamina kribrosa di saraf optik, yang menyebabkan keterlibatan seluruh retina. Pemeriksaan foto fundus mata kiri pada pasien ini kesan CRVO. Berdasarkan anamnesis dan pemeriksaan oftalmologi ditegakkan diagnosis CRVO tipe iskemik. ${ }^{8}$

Pada kepustakaan disebutkan bahwa CRVO dikenal dengan iskemik atau retinopati hemoragik dimana didapatkan setidaknya luas area kapiler non perfusi 10 disk pada pemeriksaan Fundus Fluorescein Angiografi (FFA). Pemeriksaan oftalmologi lengkap harus dilakukan pada kedua mata meliputi visus, refleks pupil, dan Tekanan Intra okular (TIO). Pemeriksaan gonioskopi berguna untuk mendeteksi apakah terdapat Neovaskuler Iris (NVI) ataupun Neovaskular di sudut COA (NVA) dan juga dilakukan untuk follow up penyakit. Pada pasien ini dengan pemeriksaan slit lamp, kita tidak menemukan adanya NVI. Pada kasus ini seharusnya dilakukan pemeriksaan FFA untuk penilaian kondisi vaskular retina dan Optical Coherence Tomography (OCT) untuk penilaian ketebalan retina serta makula, tapi alat ini belum tersedia. Pada iskemik makular, dengan pemeriksaan FFA didapatkan perluasan zona fovea yang avaskular. Tipikal FFA pasien CRVO adalah ditemukannya memanjangnya waktu sirkulasi retinovaskular. OCT bisa mengevaluasi secara 
kuantitatif luas Cystoid Macular Edema (CME) di RVO, yang dilakukan untuk mendiagnosis dan juga follow up efektivitas setelah pemberian terapi. OCT juga menyediakan informasi mengenai lokasi dan jumlah cairan di lapisan retina dan sub retina. Spectral domain OCT (SD-OCT) apabila terlihat hiperreflektif dot terutama di lapisan outer retina, bisa dicurigai bahwa itu reaksi inflamasi dan suatu proses aktif dari penyakit, bisa juga digunakan electroretinogram untuk membedakan CRVO tipe iskemik dan non iskemik. ${ }^{9}$

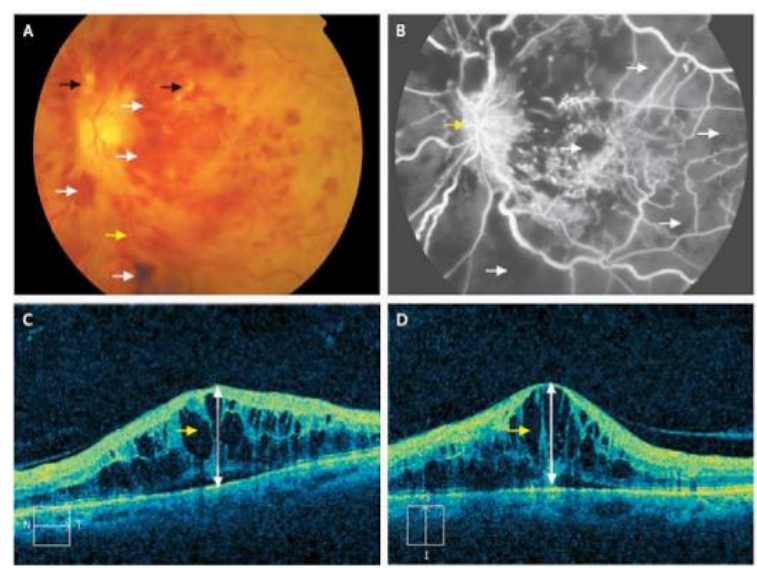

Gambar 4. Gambar A; Foto fundus memperlihatkan perdarahan intra retina yang luas (panah putih), cotton wool spot (panah hitam), edema pada diskus optikus dan hiperemia, dilatasi vena yang berkelok-kelok (panah kuning). Gambar B; Florescein Angiografi menunjukkan daerah non perfusi (panah putih). Gambar C dan D; daerah kebocoran (panah kuning) ${ }^{3}$

Pemeriksaan pencitraan tomografi optik pada potongan horizontal dan vertikal memperlihatkan penebalan retina (panah putih) dan edem makula (panah kuning). ${ }^{3}$

Patogenesis dari CRVO masih tidak jelas. Dari penelitian histopatologi ditemukan trombus yang mengobstruksi vena sentralis retina di lamina kribosa atau pada proksimal lamina kribosa. Hal ini yang menjelaskan variasi anatomi di level lamina kribosa penting dalam perkembangan CRVO. Diperkirakan pada beberapa kasus, secara histologi ditemukan penebalan arteri sentralis retina yang bergesekan dengan vena sentralis retina menyebabkan turbulensi, kerusakan endotel dan terbentuk trombus. Patogenesis oklusi vena retina dapat terjadi melalui salah satu atau kombinasi dari tiga hal berikut yaitu trombogenesis, kerusakan pembuluh darah, stasis dan hiperkoagulabilitas darah. Kerusakan dinding pembuluh darah retina akibat aterosklerosis dapat mengubah sifat rheologi vena yang terkena, menyebabkan stasis, trombosis dan akhirnya terjadi sumbatan. 8,10

Pada retrolaminar, arteri dan vena sentralis retina berjalan paralel, kemudian akan bersilangan ketika memasuki lamina kribosa, akan tetapi secara tipikal terdapat percabangan pembuluh darah kolateral sebelum memasuki lamina kribosa. Faktor lokal lainnya yang menjadi predisposisi oklusi pada CRVO meliputi kompresi oleh arteri sentralis retina yang mengalami aterosklerosis atau oklusi primer vena sentralis retina karena inflamasi. Perubahan hemodinamik mengakibatkan aliran yang stagnant dan akhirnya terbentuk trombus di vena sentralis retina termasuk berkurangnya aliran darah, meningkatnya viskositas darah dan lumen yang altered (Virchow's triad). ${ }^{3}$ Neovaskularisasi di segmen anterior dan posterior serta edem makula disebabkan oleh growth factor yang dilepaskan oleh retina yang istemik. Analisa vitreus dari pasien CRVO juga didapatkan peningkatan VEGF yang disertai dengan peningkatan sitokin dan growth factors meliputi interleukin -6 (IL-6), IL-8, interferon-induced protein-10, monocyte chemotactic protein-1 dan platelet-derived growth factor- $A A$. Level VEGF berhubungan dengan beratnya penyakit termasuk neovaskularisasi dan permeabilitas vaskular. Pada pasien ini, tidak ditemukan neovaskularisasi di segmen anterior, pemilihan penatalaksanaan pasien ini, dilakukan injeksi intravitreal triamsinolon. ${ }^{6}$

Salah satu indikasi pemberian IVTA yaitu diberikan pada pasien dengan edem makula persisten, yaitu yang sudah beberapa kali diberikan injeksi intravitreal bevacizumab. Penggantian terapi CRVO dengan pemberian IVTA, efektif untuk meningkatkan visus pasien-pasien dengan edem makula rekuren, yaitu pasien yang sudah diberikan intravitreal bevacizumab lebih dari 3 kali. $^{8}$

Pada pasien ini diberikan injeksi triamsinolon intravitreal $4 \mathrm{mg} / 0.1 \mathrm{ml}$ pada mata kiri pada tanggal 16 desember 2015. Pada minggu ke 4 post injeksi triamsinolon intravitreal mata kiri, terdapat peningkatan 
visus menjadi $1 / 60$. Kemungkinan peningkatan visus dikarenakan edem makula berkurang. Hal ini bisa dinilai dengan pemeriksaan OCT, akan tetapi alat belum tersedia. TIO mata kiri $15 \mathrm{mmHg}$. Tidak ada komplikasi dalam satu hari setelah operasi. Komplikasi segera yang sering terjadi setelah tindakan IVTA adalah peningkatan $\mathrm{TIO}$.

Beberapa komplikasi yang bisa terjadi karena pemberian IVTA seperti perdarahan sub konjungtiva post injeksi, terutama pada pasien yang mengkonsumsi anti koagulasi sistemik ataupun penyuntikan yang kurang hati-hati. Komplikasi lainnya seperti katarak traumatika, ablasio retina karena traksi vitreus ataupun jarum yang langsung mengenai retina saat menginjeksikan, dan perdarahan vitreus. Kortikosteroid juga bisa menyebabkan hipertensi okular, glaukoma dan juga katarak. Endoftalmitis yang sering didapatkan adalah endoftalmitis steril yang disebabkan oleh migrasi triamsinolon ke COA. Pada pasien ini, saat kontrol minggu ke 8 , didapatkan perdarahan sub hyaloid. Hal ini diperkirakan terjadi karena pasien tidak teratur kontrol gula darah ke penyakit dalam. ${ }^{11,12,13}$

Penelitian yang dilakukan oleh Sonmez dan Ozturk tahun 2012 didapatkan 3 karakteristik utama yang merupakan faktor resiko utama komplikasi pemberian IVTA terhadap peningkatan tekanan intraokular (TIO) yaitu TIO sebelum tindakan IVTA yang tinggi, laki-laki, dan usia muda. ${ }^{12}$

Pemilihan injeksi kortikosteroid pada CRVO efektif untuk mengatasi edem makula. Mekanisme pasti kortikosteroid dalam mengatasi edem makula masih belum diketahui, tetapi diperkirakan karena efek anti inflamasi yang mengatur pelepasan sitokin, growth factors termasuk vascular endothelial growth factor (VEGF), dan anti proliferatif seperti anti VEGF. Selain itu, menjaga stabilitas blood retinal barrier dengan menurunkan permeabilitas vaskular dan juga efek neuroprotektif. Kortikosteroid intravitreal memungkinkan obat langsung ke pembuluh darah retina dan makula sehingga membatasi kemungkinan toksisitas sistemik. ${ }^{14,15}$

Penelitian yang dilakukan oleh Nakaseko et al tahun 2012 dilaporkan IVTA yang dilakukan tidak akurat menimbulkan komplikasi. Absorbsi TA yang lambat menyebabkan penurunan visus dikarenakan kekeruhan vitreus. Penyerapan TA dalam 1 hingga 6 bulan post injeksi. ${ }^{14}$

Pada penelitian Lim dan $\mathrm{Na}$ didapatkan bahwa pada pasien CRVO dengan penurunan visus yang berat yang dilakukan injeksi bevacizumab ataupun IVTA terlihat penurunan edem makula. ${ }^{15}$

Percobaan klinis terbesar yaitu studi SCORE membandingkan efektivitas dan keamanan triamsinolon intravitreal $1 \mathrm{mg}$ dan $4 \mathrm{mg}$ dengan laser fotokoagulasi. Dari studi ini diketahui bahwa tidak ada perbedaan dalam hal tajam penglihatan dan ketebalan retina setelah di follow up selama 1 tahun. Setelah 12 bulan hingga bulan ke 36 , perbaikan ketebalan retina lebih baik ditemukan pada pasien yang dilakukan fotokoagulasi laser. ${ }^{1}$

Penatalaksanaan CRVO adalah mengatasi underlying disease dan gejala sisa dari CRVO yaitu edem makula dan NV. Injeksi intravitreal yang diberikan untuk mengatasi edem makula, Panretinal Photocoagulation (PRP) diberikan sebagai terapi definitif untuk NV. Dan yang paling terpenting adalah manajemen dari semua faktor resiko sistemik penyebab CRVO.

Beberapa penatalaksanaan CRVO untuk mengatasi edem makula yaitu:

1. Terapi kortikosteroid

Mekanisme pasti kortikosteroid dalam mengatasi edem makula masih belum diketahui. Diperkirakan karena efek anti inlamasi dalam pengaturan produksi sitokin dan growth factors termasuk VEGF. Kortikosteroid juga menjaga stabilitas blood retinal barrier dengan menurunkan permeabilitas vaskular. Penelitian SCORE didapatkan peningkatan visus pada pasien yang diberikan IVTA dibandingkan dengan kelompok observasi setelah observasi 1 tahun. ${ }^{16,17}$

\section{Intravitreal anti VEGF}

Peningkatan VEGF didapatkan pada vitreus pasien CRVO. VEGF menyebabkan proliferasi sel kapiler endotel sehingga pembuluh darah tertutup dan non perfusi. Anti VEGF bisa meningkatkan aliran darah, menurunkan tekanan intra vena dan menormalkan diameter vena dan tortositasnya. ${ }^{17}$ 
Penatalaksanaan untuk NV okular terdiri dari:

1. Laser fotokoagulasi

Pada Central Vein Occlusion Study (CVOS) setelah 1 bulan follow up, didapatkan penurunan neovascularization of the iris (NVI) ataupun neovascularization of the angle (NVA) $56 \%$ pada mata yang tidak dilakukan terapi laser segera dibandingkan dengan mata yang dilakukan laser segera sebesar $22 \%$. Oleh karena itu, CVOS merekomendasikan PRP diberikan segera pada pasien yang sudah didapatkan NVI/NVA akan tetapi bukan merupakan suatu profilaksis pada CRVO tipe iskemik. Rata-rata regresi NVI/NVA didapatkan pada 90\% kasus setelah 1-2 bulan diberikan PRP. ${ }^{18,19}$

\section{Terapi medikamentosa}

Obat-obatan topikal maupun sistemik anti glaukoma mungkin diperlukan untuk menurunkan TIO. Topikal kortikosteroid diperlukan untuk menurunkan inflamasi di segmen anterior dengan menstabilkan tight junction di jaringan NV. Sikloplegik mencegah terbentuknya sinekia. ${ }^{16}$ Terapi medikamentosa untuk kondisi sistemik diperlukan untuk mengatasi semua faktor resiko CRVO dan memerlukan kerjasama dengan bagian penyakit dalam. Peranan dari sistemik anti koagulasi masih belum jelas, karena meskipun pasien memakai warfarin sodium, tetap bisa terjadi CRVO. Akan tetapi, profilaksis medikamentosa ini bisa mencegah trombus non okular, terutama pada pasien dengan penyakit vaskular sistemik. Meningkatnya viskositas plasma pada pasien CRVO akan meningkatkan hemodilusi dan meningkatkan kebutuhan oksigen ke retina. ${ }^{17,18}$

Terapi alternatif pada CRVO terdiri dari:

1. Terapi surgikal vitrektomi

Dilakukan untuk evakuasi perdarahan vitreus karena NV di retina. Saat dilakukan vitrektomi, bisa dilakukan juga membersihkan membran epiretinal dan proliferasi fibrovaskular dan disertai endolaser PRP. ${ }^{18}$

2. Radial optic neurotomy (RON)

Merupakan teknik mengkombinasikan vitrektomi dengan RON yang meliputi insisi transvitreal dari nasal scleral ring untuk melepaskan tekanan di vena sentralis retina. Pada penelitian yang dilakukan oleh
Chen et al (2016), memungkinkan perbaikan tajam penglihatan pada bulan ke 12 , dan menurunkan resiko glaukoma neovaskuler. RON memiliki resiko yang signifikan seperti defek lapangan pandang post operasi, laserasi dari pembuluh darah retina, perforasi bola mata, CNV, dan ablasio retina. Dengan meningkatnya pengetahuan mengenai efektivitas obatobat intravitreal, tindakan RON pada pasien CRVO sudah tidak dilakukan. ${ }^{20}$

\section{SIMPULAN}

Manajemen penatalaksanaan CRVO antara lain bertujuan untuk mengatasi edem makula dan mencegah NV, Triamcinolone acetonide merupakan suatu kortikosteroid dari golongan agonis sintetik glukokortikoid yang di indikasikan salah satunya pada kasus CRVO. Pemberian IVTA dapat mengatasi edem retina dengan menurunkan inflamasi, menstabilkan blood retinal barrier, efek obat langsung ke retina dan juga efek neuroprotektif.

\section{SARAN}

Injeksi intravitreal triamsinolon disarankan untuk terapi CRVO terutama untuk mengatasi edem makula.

\section{UCAPAN TERIMAKASIH}

Terimakasih kepada Ketua Program Studi IImu Kesehatan Mata Program Pendidikan Dokter Spesialis Fakultas Kedokteran Universitas Andalas dan Ketua Bagian IImu Kesehatan Mata RS Dr.M.Djamil Padang yang telah membantu dalam penulisan kasus ini.

\section{DAFTAR PUSTAKA}

1. Cantor LB, Rapuano CJ, Cioffi GA. Retina and vitreous. Section 12. San Francisco: American Academy of Ophthalmology; 2018-2019.hlm.102-7.

2. Oellers $P$, Hahn $P$, Fekrat $S$. Central retinal vein occlusion. Dalam: Schachat AP, Sadda SR, editor (penyunting). Ryan's Retina. Edisi ke-5. China: Elsevier; 2018.hlm.1166-76.

3. Wong TY, Scott IU. Retinal-vein occlusion. New England Journal of Medicine. 2010;363: 2135-44.

4. The Royal Australian and New Zealand College of Ophthalmologists. Clinical Practice Guidelines for 
The Use of Intravitreal Triamcinolone Acetonide. Australia: Ranzco; 2014.hlm.1-8.

5. Christine RN, Agni AN. Diagnosis oklusi pembuluh darah retina. Majalah Kedokteran FK UKI. 2012; 28:194-9.

6. Keren S, Loewenstein A, Coscas G. Pathogenesis, prevention, diagnosis and management of retinal vein occlusion. World Journal of Ophtalmology. 2014;4:92-112.

7. Kolar P. Definition and classification of retinal vein occlusion. International Journal of Ophthalmic Research. 2016;2:1-12.

8. Alshareef RA, Garg SJ, Hsu J, Vander J, Park C, Spirn MJ. Intravitreal triamcinolone acetonide injection for macular edema due to central retinal vein occlusion persisting despite multiple intravitreal bevacizumab injections. Journal of Ocular Pharmacology and Therapeutics. 2014; 30: 512-7.

9. Keane PA, Tan CS, Singer MA, Sadda SV. Role of imaging in the management of macular edema secondary to retinal vein occlusion. Dalam: Hariprasad SM, editor (penyunting). Management of Retinal Vein Occlusion. USA: SLACK; 2014.hlm.79-112.

10. Kulkarni A, Michael S. Corticosteroid therapies in the management of macular edema secondary to retinal vein occlusion. Dalam: Hariprasad SM, editor (penyunting). Management of Retinal Vein Occlusion. USA: SLACK; 2014.hlm.63-78.

11. Aref AA, Scott IU, Oden NL, Michael S, Blodi BA, et al. Incidence, risk factors, and timing of elevated intraocular pressure after intravitreal triamcinlone acetonide injection for macular edema secondary to retinal vein occlusion. Jama Ophthalmology. 2015;1:1-8.
12. Sonmez K, Ozturk F. Complications of intravitreal triamcinolone acetonide for macular edema and predictive factors for intraocular pressure elevation. International Journal Ophthalmol. 2012;6:719-25.

13. Shahsuvaryan ML. Central retinal vein occlusion: current therapeutic approach. Bulletin of Environment, Pharmacology and Life Sciences. 2012;1:1-8.

14. Nakaseko $Y$, Kamatani $M$, Kondo $M$, Uji $Y$, Sugimoto M. Complications following inappropriate intravitreal triamcinolone acetonide injection. Open Journal of Ophthalmology. 2012;2:114-5.

15. Lim JW, Na KI. A comparative study between intravitreal triamsinolone and bevacizumab for makular edema due to central retinal vein occlusion with poor vision. Indian Journal of Pharmacology. 2011;9:93-6.

16. Ford JA, Clar C, Lois N, Barton S, Thomas S, Court R. Treatments for macular edema following central retinal vein occlusion: systematic review. British Medical Journal. 2013;4:1-11.

17. Bowling B. Retinal vascular disease. Kanski's clinical ophthalmology. Edisi ke-8. China: Elsevier; 2016.hlm.542-9.

18. Kumagai K, Ogino N, Fukami M, Furukawa M. Vitrectomy for macular edema due to retinal vein occlusion. Clinical Ophthalmology. 2019;13:96984.

19. Li C, Wang R, Liu G, Ge Z, Jin D, Ma Y, et al. Efficacy of panretinal laser in ischemic central retinal vein occlusion: a systemic review. Experimental And Therapeutic Medicine. 2019;17: 901-10.

20. Chen ZN, Shao Y, Li XR. Radial optic neurotomy in treating central retinal vein occlusion: a meta analysis. J Ophthalmol. 2016;9:898-903. 